CORRECTION OPEN

Check for updates

\title{
Correction to: APOE4 genotype exacerbates the depression-like behavior of mice during aging through ATP decline
}

Wenting Fang, Naian Xiao, Guirong Zeng, Daode Bi, Xiaoman Dai, Xue Mi, Qinyong Ye, Xiaochun Chen and Jing Zhang (D)

(c) The Author(s) 2021

Translational Psychiatry (2021)11:603; https://doi.org/10.1038/s41398-021-01721-z

Correction to: Translational Psychiatry https://doi.org/10.1038/

s41398-021-01631-0, published online 5 October 2021

The original version of this article unfortunately contained a mistake in Figure 2A. The authors apologize for the mistake. The original article has been corrected.

A

[18F]-FDG

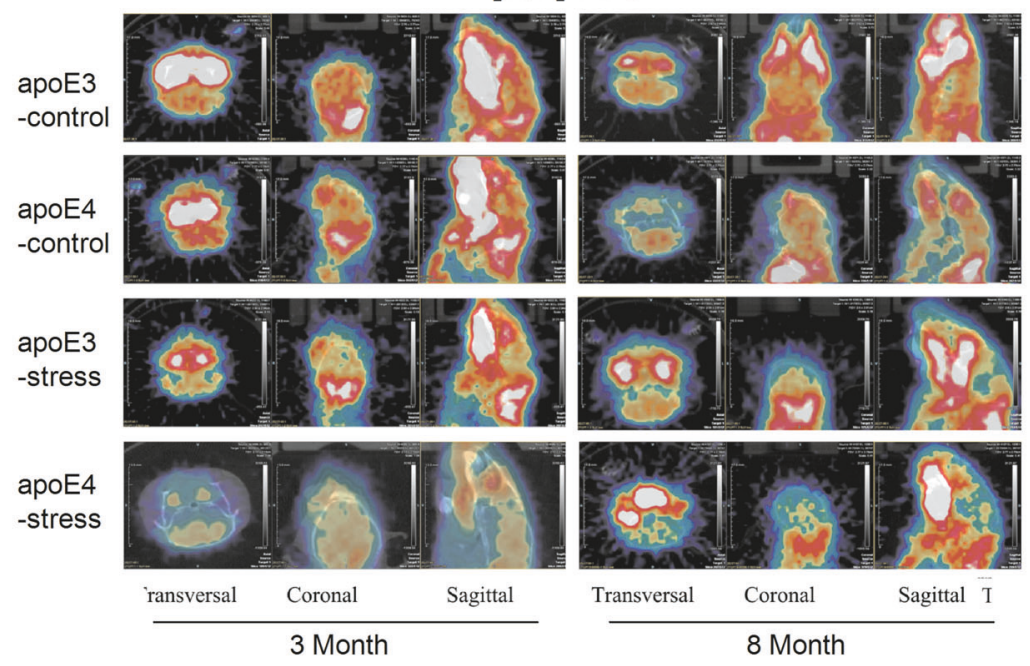

B

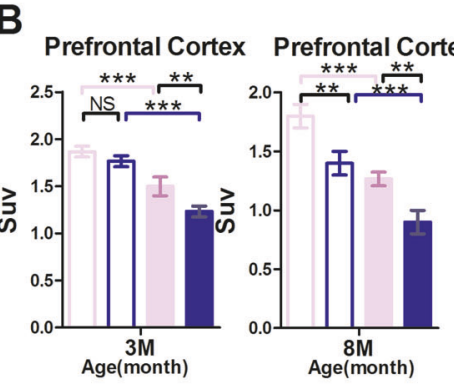

C
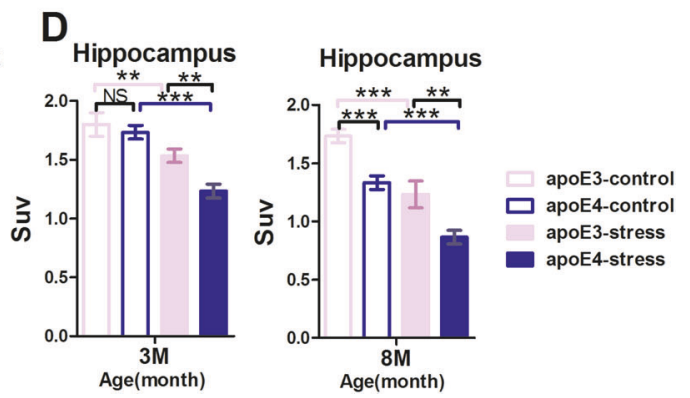

Fig. 2

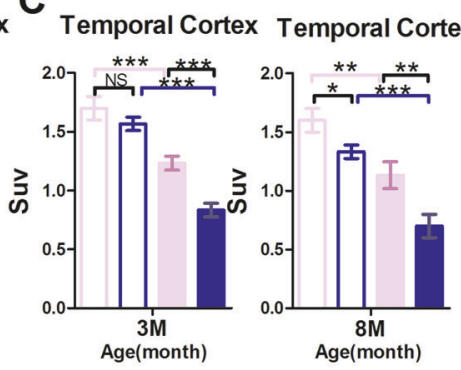


(c) Open Access This article is licensed under a Creative Commons Attribution 4.0 International License, which permits use, sharing, adaptation, distribution and reproduction in any medium or format, as long as you give appropriate credit to the original author(s) and the source, provide a link to the Creative Commons license, and indicate if changes were made. The images or other third party material in this article are included in the article's Creative Commons license, unless indicated otherwise in a credit line to the material. If material is not included in the article's Creative Commons license and your intended use is not permitted by statutory regulation or exceeds the permitted use, you will need to obtain permission directly from the copyright holder. To view a copy of this license, visit http://creativecommons. org/licenses/by/4.0/.

(c) The Author(s) 2021 